$\overline{\text { Original }}$

\title{
Factors Affecting the Survival of Exogenous Bacteria in Microbial Ecosystems: Existence of Indigenous Bacteria with Antagonistic Activity
}

\author{
SATOSHI SODA, HISAMI WATATANI, MICHIHIKO IKE, \\ AND MASANORI FUJITA* \\ Department of Environmental Engineering, Osaka University, \\ 2-1, Yamada-oka, Suita, Osaka 565-0871, Japan
}

Received 18 December 1997/Accepted 3 March 1998

\begin{abstract}
The survival of Escherichia coli K-12 and Pseudomonas putida BH inoculated into fresh water, sea water, activated sludge, and soil microcosms was studied. Three kinds of microcosms, named as intact, protozoa-free (filtered with $1.0 \mu \mathrm{m}$ filter or $2.0 \mathrm{~g} / \mathrm{l}$ of cycloheximide added), and sterilized microcosms (filtered with $0.22 \mu \mathrm{m}$ filter or autoclaved twice at $120^{\circ} \mathrm{C}$ for $20 \mathrm{~min}$.), were made from each kind of environmental sample, and used for the survival studies in order to separately evaluate the general effects of protozoan predation, interaction with indigenous bacteria, and starvation. In the all intact microcosms, both exogenous bacterial populations decreased rapidly by 1 to 4 orders of magnitude over $7 \mathrm{~d}$. The experimental results indicated that the interaction with indigenous bacteria, especially in the form of antagonism or amensalism, was the most influential factor causing the decline of the exogenous bacterial populations, and that the protozoan predation was much less influential. To demonstrate evidence for the presence of such antagonism, heterotrophic bacteria indigenous to each intact microcosms were isolated, and their antagonistic activities against the introduced exogenous bacteria were examined. Approximately 1.0-3.5\% of the isolated bacterial strains showed antagonistic activity against either $E$. coli K-12 or P. putida BH. However, the antagonistic activity exerted by most strains was found to be unstable.
\end{abstract}

Key words : Antagonism/Exogenous bacteria/Microcosm/Survival.

\section{INTRODUCTION}

Recently, there has been much concern regarding the intentional release to natural or semi-natural ecosystems of exogenous bacteria, including genetically engineered bacteria, with desirable capabilities for bioremediation of polluted environments and control of insects or plant pathogens (Lindow et al., 1989; Ramos et al., 1994). For the introduction of exogenous bacteria (bioaugmentation) to be successful, it is necessary that these bacteria survive at significantly high levels and exhibit their useful qualities in the microbial ecosystems. However, many research-

*Corresponding author. Tel: +81-6-879-7672, Fax: +816-879-7675. ers have reported that such exogenous bacteria, after being introduced to certain environments, drastically decreased or disappeared in a variety of microcosms including fresh water (Amy et al., 1989; Barcina et al., 1992; Brettar et al, 1994; Gurijara and Alexander, 1990; Iwasaki et al., 1993; Klein and Alexander, 1986; Sinclair and Alexander, 1984; Zaidi et al., 1989), sea water (Leser et al., 1995; Mezrioui et al., 1995), biological wastewater treatment processes (Fujita et al., 1994; McClure et al., 1989; Nüblein et al., 1992), and soils (Bolton et al., 1991; Macnaughton et al., 1992; Ramos et al., 1991; Recorbet et al., 1993; Tang and Alexander 1987). This decline or disappearance indicated that the inoculated bacteria encountered some lethal factors in the microbial ecosystems. The survival of bacteria inoculated into new ecosystems 
would seem to depend on their ability to tolerate a set of abiotic and biotic factors which cause lethal effects.

Several abiotic factors affecting the survival of exogenous bacteria have been suggested such as $\mathrm{pH}$, temperature (Bolton et al., 1991), radiation (Barcina et al., 1992), nutrients (Sinclair and Alexander, 1989), toxins (Klein and Alexander, 1986), and osmotic pressure (Mezurioui et al., 1995). On the other hand, influential biotic factors are considered to include the growth/decay properties of exogenous bacteria and microbial interactions such as competition with indigenous bacteria and predation by protozoa (Amy et al., 1989; Gurijara and Alexander, 1990; Iwasaki et al., 1993; Sinclair and Alexander, 1984; Tang and Alexander, 1987). The knowledge of such factors should facilitate the assessment of the likelihood that exogenous bacteria inoculated into natural environments will survive and help to select bacteria whose period of survival may be either long or short as desired for particular functions or uses. However, not much useful knowledge has been obtained to date especially on the biotic factors, and further studies are required to obtain more generalized knowledge.

In this study, we introduced Escherichia coli K-12 and Pseudomonas putida $\mathrm{BH}$ as exogenous bacteria into fresh water, sea water, activated sludge, and soil microcosms, and the general influences of protozoa, indigenous bacteria, and starvation on their course of survival were separately evaluated. As a whole, the experimental results suggested that the interaction with indigenous bacteria, especially in the form of antagonism or amensalism, is the most influential factor causing the drastic decrease of exogenous bacteria in natural ecosystems. To confirm the presence of such antagonism in natural environments, screening of bacteria with antagonistic activities against the exogenous bacteria was also performed.

\section{MATERIALS AND METHODS}

\section{Bacterial strains}

E. coli K-12 and P. putida BH (Fujita et al., 1991) were used as exogenous bacteria which were introduced into microcosms. The recombinant plasmid pBH500 (Fujita et al., 1994) was introduced into both bacterial strains to give specific selective markers, resistance to streptomycin ( $\mathrm{Sm}$ ) and expression of a catechol 2,3-oxygenase gene (pheB). Colonies expressing $p h e B$ quickly turn yellow when sprayed with $0.1 \mathrm{mM}$ catechol solution.

\section{Culture Media}

Counts of $E$. coli $\mathrm{K}-12$ and $P$. putida $\mathrm{BH}$ inoculated into microcosms were determined on Desoxycolate agar (Eiken Chemical Co.) and a basal salt medium (BSM) (Fujita et al., 1994) containing $500 \mathrm{mg} / \mathrm{l}$ benzoate, respectively. Both media were supplemented with $50 \mathrm{mg} / l \mathrm{Sm}$. The combination of these selective media and spraying colonies with catechol enabled specific detection of the exogenous bacteria in all the microcosms used with a detectable limit of $10 \mathrm{CFU/}$ $\mathrm{ml}$ of aquatic samples or $10 \mathrm{CFU} / \mathrm{g}$-dry weight of soil. Yoshikura 0.05 medium (glucose $0.1 \mathrm{~g}$, yeast extract $0.25 \mathrm{mg}$, peptone $0.5 \mathrm{mg}$, and agar $15 \mathrm{~g}$ in 1 liter) was used for counting and isolating indigenous heterotrophic bacteria in fresh water and sea water microcosms. Yoshikura 0.05 medium was prepared with deionized water $(\mathrm{pH}$ 7.2) or with artificial sea water $\left(\mathrm{NaCl} 30 \mathrm{~g}, \mathrm{KCl} 0.7 \mathrm{~g}, \mathrm{MgCl}_{3} \cdot 6 \mathrm{H}_{2} \mathrm{O} 10.8 \mathrm{~g}, \mathrm{MgS}\right.$ $\mathrm{O}_{4} 5.4 \mathrm{~g}, \mathrm{CaCl}_{2} \cdot 2 \mathrm{H}_{2} \mathrm{O} 1.0 \mathrm{mg}, \mathrm{FeSO}_{4} \cdot 7 \mathrm{H}_{2} \mathrm{O} 1.0 \mathrm{mg}$, and $\mathrm{MnSO}_{4} \cdot 4 \mathrm{H}_{2} \mathrm{O} 1.0 \mathrm{mg}$ in 1 liter of deionized water: $\mathrm{pH}$ 7.9) for fresh water or sea water bacteria, respectively. For indigenous heterotrophic bacteria in activated sludge, CGY medium (Pike et al., 1972) was used. Indigenous heterotrophic bacteria and fungi in soil were enumerated on PYG medium (poly-peptone $10 \mathrm{~g}$, yeast extract $5 \mathrm{~g}$, glucose $20 \mathrm{~g}$, and agar $15 \mathrm{~g}$ in 1 liter of deionized water: $\mathrm{pH}$ 7.2) and Rose-Bengal medium (Rose Bengal $33 \mathrm{mg}, \mathrm{KH}_{2} \mathrm{PO}_{4} 1.0 \mathrm{~g}, \mathrm{MgSO}_{4}$. $7 \mathrm{H}_{2} \mathrm{O} 0.5 \mathrm{~g}$, peptone $5 \mathrm{~g}$, glucose $10 \mathrm{~g}$, and agar $20 \mathrm{~g}$ in 1 liter of tap water: $\mathrm{pH} 6.8$ ), respectively. For routine maintenance of the bacterial strains, LB broth (Sambrook et al., 1989) was used.

\section{Microcosms}

Characteristics of the environmental samples used for preparing microcosms for the survival studies are shown in Table 1. The characteristics of fresh water, sea water, and activated sludge samples were measured according to the methods delineated in JIS (Japan Industrial Standards) K0102. Dissolved organic carbon in the soil samples was measured by a TOC-500 analyzer (Shimidzu Co.) for filtered samples with 1.0- $\mu \mathrm{m}$-pore-size glass microfibre filters (Whatman Co.) after treatment with a sonicater (UD201: TOMY Co.) for $5 \mathrm{~min}$ to disperse soil particles, and $\mathrm{pH}\left(\mathrm{H}_{2} \mathrm{O}\right)$ was measured according to JGS

TABLE 1 . Properties of environmental samples used for making microcosms.

\begin{tabular}{lccc}
\hline \multirow{2}{*}{ Sample } & $\mathrm{pH}$ & \multicolumn{2}{c}{ Content of } \\
\cline { 3 - 4 } & & $\begin{array}{c}\text { Dissolved } \\
\text { organic carbon }\end{array}$ & $\begin{array}{c}\text { Suspended } \\
\text { solid }\end{array}$ \\
\hline Fresh water & 7.2 & $4.0 \mathrm{mg} / l$ & $10 \mathrm{mg} / l$ \\
Sea water & 7.9 & $11 \mathrm{mg} / l$ & $270 \mathrm{mg} / l$ \\
Activated sludge & 7.2 & $10 \mathrm{mg} / l$ & $1400 \mathrm{mg} / l$ \\
Soil & 6.4 & $12 \mathrm{mg} / \mathrm{dry}-\mathrm{g}$ & - \\
\hline
\end{tabular}


(Japan geological standard) T-211. The fresh water and sea water samples were respectively collected from Zuion Pond (Osaka Prefecture) in June, 1996 and from Miura Coast (Kanagawa Prefecture) in January, 1997. The activated sludge was obtained from a municipal sewage treatment plant (Osaka Prefecture) in July, 1996. The soil sample was taken from a $0-10 \mathrm{~cm}$ depth of an agricultural field in Toyonaka City (Osaka Prefecture) in July, 1996. Three kinds of microcosms were prepared from each environmental sample: an intact, protozoa-free, and sterilized microcosm.

Fresh water and sea water microcosms consisted of $300-\mathrm{ml}$ Erlenmeyer flasks containing a $100 \mathrm{ml} \mathrm{sam}$ ple. The fresh water and sea water samples were used as the intact microcosms without any treatment. For preparing the protozoa-free and sterilized microcosms, the samples were filtered with $1.0-\mu \mathrm{m}$-poresize glass microfibre filters (Whatman Co.) and with $0.22-\mu \mathrm{m}$-pore-size cellulose nitrate membrane filters (Advantec Toyo Co.), respectively. Activated sludge microcosms also consisted of 300-ml Erlenmeyer flasks containing a $100 \mathrm{ml}$ sample. The freshly obtained activated sludge was washed twice with $5 \mathrm{mg}$ $/ l$ sterile sodium tripolyphosphate solution (tpp) to remove dissolved organic carbon in the liquid phase, resuspended in the original volume of the BSM, and used as the intact microcosm. An eucaryotic inhibitor, cycloheximide $(2.0 \mathrm{~g} / l)$, was added to the washed activated sludge for preparing the protozoa-free microcosm. The sterilized microcosm was obtained by autoclaving $\left(120^{\circ} \mathrm{C}, 20 \mathrm{~min}\right)$ the washed activated sludge. Soil microcosms consisted of cotton-plugged $300-\mathrm{ml}$ Erlenmeyer flasks containing $100 \mathrm{~g}$ of a soil sample. The soil sample was sieved through a 2.0$\mathrm{mm}$ screen, moistened to $30 \%(\mathrm{w} / \mathrm{w})$ with sterile deionized water, and a $100 \mathrm{~g}$ aliquot was placed in a flask as the intact microcosm. For preparing the sterilized microcosm, the soil sample was autoclaved twice at $120^{\circ} \mathrm{C}$ for $20 \mathrm{~min}$. The protozoa-free microcosm could not be made for the soil sample.

\section{Survival studies}

E. coli $\mathrm{K}-12$ and $P$. putida $\mathrm{BH}$ were grown overnight to the mid-log phase in LB broth supplemented with $\mathrm{Sm}(50 \mathrm{mg} / \mathrm{l})$. Cells were harvested by centrifugation at $1500 \times \mathrm{g}$ at $4^{\circ} \mathrm{C}$ for $10 \mathrm{~min}$, washed twice with tpp, and inoculated into the microcosms at appropriate densities. The fresh water, sea water, and activated sludge microcosms were incubated at $28^{\circ} \mathrm{C}$ on a rotary shaker operating at $100 \mathrm{rpm}$, while the soil microcosms were incubated statically at $25^{\circ} \mathrm{C}$. All the microcosms were maintained in the dark conditions to omit the effect of phytoplankton.
The numbers of surviving exogenous bacteria and behavior of indigenous microorganisms were monitored periodically. Bacteria in the microcosms were counted by plate count techniques using the abovementioned media. Samples obtained from the fresh water and sea water microcosms were completely mixed with a vortex mixer before being plated onto the media. Samples from the activated sludge microcosms were treated with a sonicator (UD201: TOMY Co.) to disperse the sludge flocs (Fujita et al., 1994) for bacterial enumeration. The soil samples were suspended in tpp ( $1 \mathrm{~g}$-wet weight in $10 \mathrm{ml}$ ), and mixed vigorously with a vortex mixer for 2-3 min. The resultant supernatant was used for plating. All the plates were incubated at $28^{\circ} \mathrm{C}$ for $2 \mathrm{~d}$ for counting $E$. coli K12 and $P$. putida $\mathrm{BH}$, and for 7-10 d for counting fungi and indigenous heterotrophic bacteria. Protozoa except small types such as nano-flagellates in the fresh water and activated sludge microcosms were measured with a phase contrast microscope at $100 \times$ or $200 \times$ magnification.

As control experiments, the survival of the exogenous bacteria in sterile buffers containing no carbon source was investigated for evaluating the effect of starvation. The buffers used for this purpose were $\mathrm{BSM}$ and artificial sea water.

\section{Screening of antagonistic bacteria}

Bacteria which inhibit the growth of the exogenous bacteria, E. coli $\mathrm{K}-12$ or $P$. putida $\mathrm{BH}$, were defined as antagonistic bacteria. About 200 colonies of indigenous heterotrophic bacteria were isolated from each environmental sample (the intact microcosm) by using an appropriate medium (Yoshikura 0.05, CGY medium, or PYG medium), and grown at $28^{\circ} \mathrm{C}$ for $3-5 \mathrm{~d}$. A small amount of cell paste was scraped off and deposited onto the surface of the same medium plates seeded with $E$. coli $\mathrm{K}-12$ or $P$. putida $\mathrm{BH}$, and the plates were incubated at $28^{\circ} \mathrm{C}$ for $2-3 \mathrm{~d}$. A clear zone of inhibition formed around the bacteria from the paste indicated the antagonistic activity against $E$. coli $\mathrm{K}-12$ or $P$. putida $\mathrm{BH}$.

\section{RESULTS}

\section{Survival of exogenous bacteria in fresh water microcosms}

The survival patterns of the exogenous bacteria in the fresh water microcosms and in the sterile buffer (BSM) are shown in Figs. 1 and 2. E. coli K-12 and $P$. putida $\mathrm{BH}$ were inoculated into the microcosms at densities of $4.5 \times 10^{4}$ and $2.2 \times 10^{4} \mathrm{CFU} / \mathrm{ml}$, respectively. Although the protozoa-free microcosms contained microorganisms smaller than $1.0 \mu \mathrm{m}$, large 


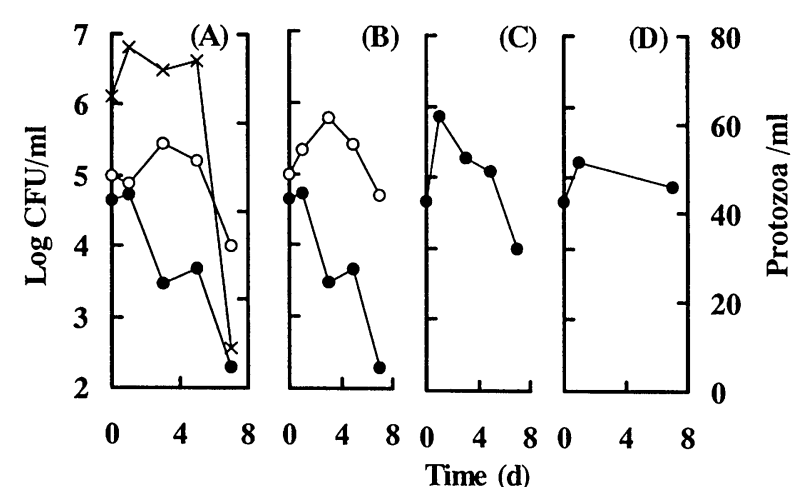

FIG. 1 . Survival of $E$. coli $\mathrm{K}-12$ in the fresh water microcosms. Populations of $E$. coli $\mathrm{K}-12(\mathbf{O})$, indigenous heterotrophic bacteria $(O)$, and protozoa $(X)$ in the intact microcosm $(A)$, protozoa-free microcosm $(B)$, sterilized microcosm (C), and sterile basal salt medium (D) are shown.

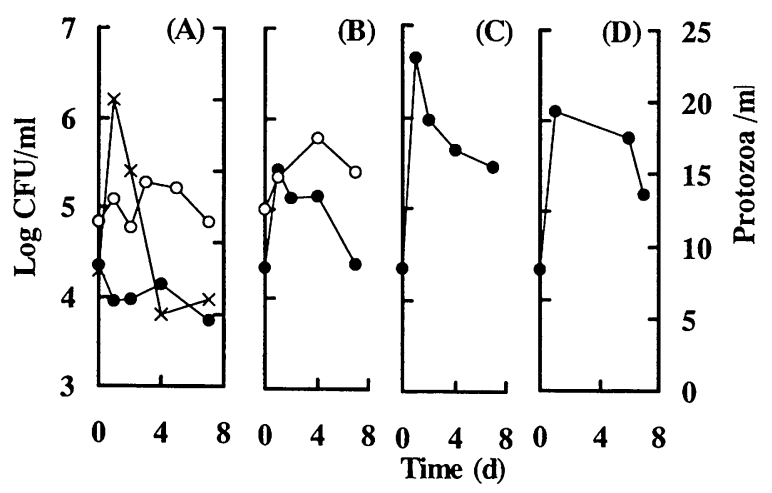

FIG. 2. Survival of $P$. putida $B H$ in the fresh water microcosms. Populations of $P$. putida $\mathrm{BH}(\mathbf{O})$, indigenous heterotrophic bacteria $(O)$, and protozoa $(X)$ in the intact microcosm $(A)$, protozoa-free microcosm (B), sterilized microcosm (C), and sterile basal salt medium (D) are shown.

protozoa were not observed. The sterilized microcosms contained indigenous bacteria smaller than 0.2 $\mathrm{mm}$ and bacteriophages; however, there was no formation of indigenous colonies on Yoshikura 0.05 medium.

E. coli $\mathrm{K}-12$ declined 2 orders of magnitude in population over $7 \mathrm{~d}$ in the intact and protozoa-free microcosms. However, it maintained a relatively steady population in the sterilized microcosm and in the sterile buffer.

P. putida $\mathrm{BH}$ decreased to about $25 \%$ of the initial level within a week in the intact microcosm, and it increased by $2-3$ orders of magnitude in population on day 1 and, subsequently, decreased in the sterilized microcosm and in the sterile buffer, although the

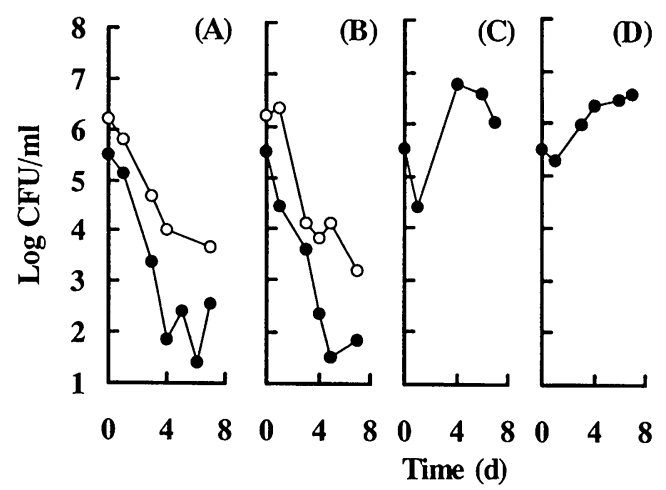

FIG. 3. Survival of $E$. coli $\mathrm{K}-12$ in the sea water microcosms. Populations of $E$. coli $\mathrm{K}-12$ ( $)$ and indigenous heterotrophic bacteria $(O)$ in the intact microcosm (A), protozoa-free microcosm (B), sterilized microcosm (C), and sterile artificial sea water (D) are shown.

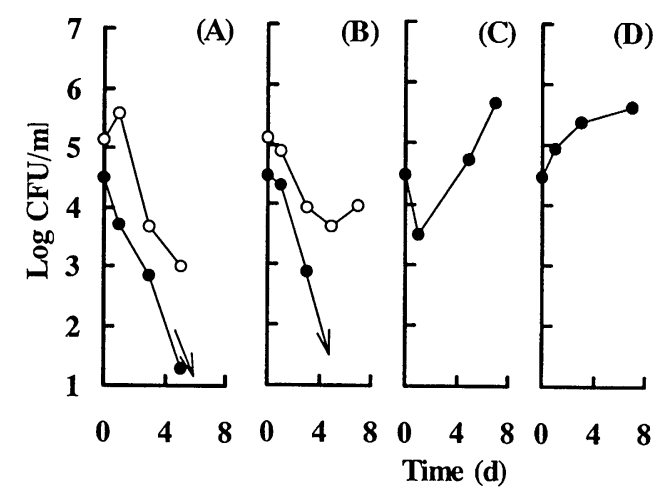

FIG. 4. Survival of $P$. putida $\mathrm{BH}$ in the sea water microcosms. Populations of $P$. putida $\mathrm{BH}(\mathbf{O})$ and indigenous heterotrophic bacteria $(O)$ in the intact microcosm $(A)$, protozoa-free microcosm (B), sterilized microcosm (C), and sterile artificial sea water (D) are shown. Arrows indicate that the viable counts at the next time point had reached an undetectable level.

survival levels after $7 d$ were considerably higher than the inoculated level. In the protozoa-free microcosm, the population of $P$. putida $\mathrm{BH}$ declined, then showed a slight cell growth, and decreased again to approximately the original level.

\section{Survival of exogenous bacteria in sea water microcosms}

Results of the survival studies of $E$. coli $\mathrm{K}-12$ and $P$. putida $\mathrm{BH}$ in the sea water microcosms are shown in Figs. 3 and 4 , respectively. The artificial sea water was used as the sterile buffer in this study. These exogenous bacteria were introduced into the microcosms at ca. $3.0 \times 10^{5} \mathrm{CFU} / \mathrm{ml}$. Large protozoa were not observed in the protozoa-free microcosms, and no 


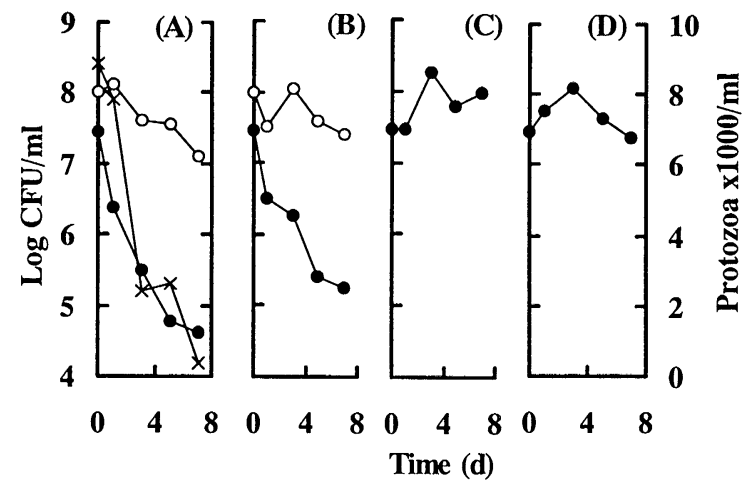

FIG.5. Survival of $E$. coli $\mathrm{K}-12$ in the activated sludge microcosms. Populations of E. coli K-12 (O), indigenous heterotrophic bacteria $(O)$, and protozoa $(X)$ in the intact microcosm (A), protozoa-free microcosm (B), sterilized microcosm (C), and sterile basal salt medium (D) are shown.

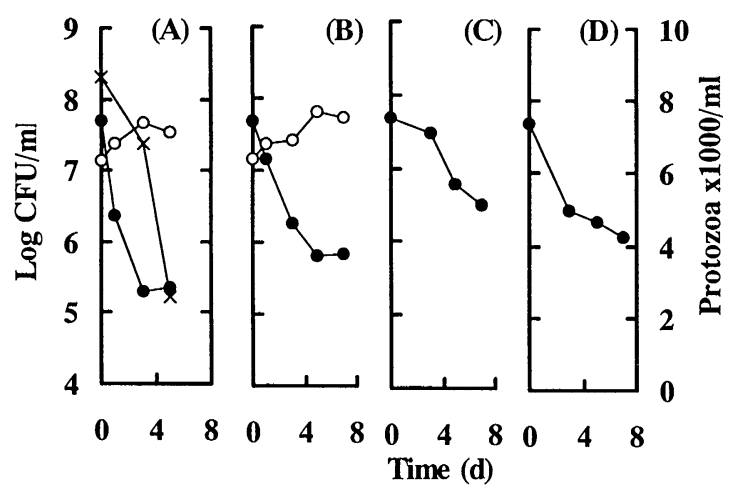

FIG.6. Survival of $P$. putida $\mathrm{BH}$ in the activated sludge microcosms. Populations of $P$. putida $\mathrm{BH}(\mathbf{O})$, indigenous heterotrophic bacteria $(O)$, and protozoa $(X)$ in the intact microcosm (A), protozoa-free microcosm (B), sterilized microcosm (C), and sterile basal salt medium (D) are shown.

indigenous bacteria were recovered from the sterilized microcosms.

As shown in the figures, both types of exogenous bacteria showed very similar survival patterns. Their numbers declined more than 4 orders of magnitude over $7 \mathrm{~d}$ in the intact and protozoa-free microcosms, while they increased substantially in the sterile microcosms and in the sterile buffers during the experimental periods.

\section{Survival of exogenous bacteria in activated sludge microcosms}

Results of the survival studies of the exogenous bacteria in the activated sludge microcosms are shown in Figs. 5 and 6. E. coli K-12 and P. putida $\mathrm{BH}$ were inoculated into the microcosms at densities of

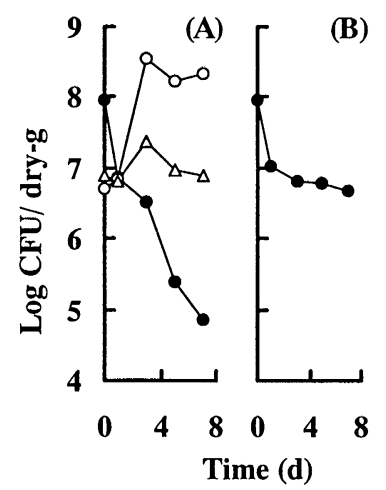

FIG. 7. Survival of $E$. coli $\mathrm{K}-12$ in the soil microcosms. Populations of $E$. coli $\mathrm{K}-12(\mathbf{O})$, indigenous heterotrophic bacteria $(O)$, and indigenous fungi $(\triangle)$ in the intact micro$\operatorname{cosm}(\mathrm{A})$ and sterilized microcosm (B) are shown.

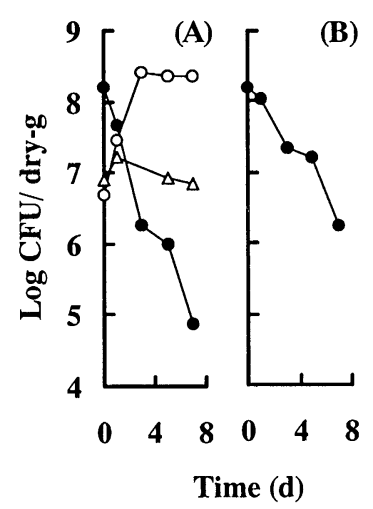

FIG. 8. Survival of $P$. putida $\mathrm{BH}$ in the soil microcosms. Populations of $P$. putida $\mathrm{BH}(\mathbf{O})$, indigenous heterotrophic bacteria $(O)$, and indigenous fungi $(\triangle)$ in the intact microcosm (A) and sterilized microcosm (B) are shown.

$2.9 \times 10^{7}$ and $5.0 \times 10^{8} \mathrm{CFU} / \mathrm{ml}$, respectively. Large viable protozoa were not observed in the protozoafree microcosms, and no indigenous bacteria were recovered from the sterilized microcosms. The intact microcosm inoculated with $P$. putida $\mathrm{BH}$ was lost due to some trouble on day 6 .

Both types of exogenous bacteria declined in population by 2 to 3 orders of magnitude over 5 or $7 \mathrm{~d}$ in the intact and protozoa-free microcosms; they survived at little higher levels in the protozoa-free microcosm than in the intact microcosm. In the sterilized microcosm and in the sterile buffer, the E. coli $\mathrm{K}-12$ population was maintained at stable levels over $7 \mathrm{~d}$, while that of $P$. putida $\mathrm{BH}$ gradually decreased. Protozoa decreased drastically in the intact microcosms, and the effect of protozoan predation might 
therefore be underestimated from that in natural conditions (e.g. in the activated sludge treatment process). A decrease in the protozoan population was also observed in the intact microcosms without inoculation of the exogenous bacteria (data not shown). However, the surviving protozoa such as Zoothamnium and Aspidisca were frequently observed to show grazing activity.

\section{Survival of exogenous bacteria in soil microcosms}

The survival courses of $E$. coli K-12 and $P$. putida $\mathrm{BH}$, which were inoculated into the soil microcosms at an order of $10^{8} \mathrm{CFU} / \mathrm{g}$-soil, are shown in Figs. 7 and 8 , respectively. No indigenous colonies were recovered from the sterilized microcosms.

Both exogenous bacterial strains rapidly declined to 7-8 $\times 10^{4} \mathrm{CFU} / \mathrm{g}$-soil (3 orders of magnitude) over 7 $d$ in the intact microcosm. However, indigenous heterotrophic bacteria and fungi increased from about $10^{7}$ to $5 \times 10^{8} \mathrm{CFU} / \mathrm{g}$-soil in the intact soil microcosm. In the sterilized microcosm, the survival rates of both exogenous strains were much better than those in the intact microcosm; the decreases after $7 \mathrm{~d}$ were by about 1 order for $E$. coli $\mathrm{K}-12$ and less than 2 orders for $P$. putida $\mathrm{BH}$.

\section{Screening of indigenous bacteria with antagonistic activity}

Results of screening bacteria which exhibit the antagonistic activity against $E$. coli $\mathrm{K}-12$ and $P$. putida $\mathrm{BH}$ from the fresh water, sea water, and activated sludge samples are summarized in Table 2.

Among the bacteria isolated from each environmental sample, $1.0-3.5 \%$ showed $1-3 \mathrm{~mm}$ clear zones of inhibition, indicating antagonistic activity, and there were in total 18 strains identified as antagonistic to $E$. coli $\mathrm{K}-12$ and 15 to $P$. putida $\mathrm{BH}$. However, only one strain isolated from the sea water could inhibit the growth of both $E$. coli $\mathrm{K}-12$ and $P$. putida $\mathrm{BH}$. Interestingly, all the antagonistic bacteria except two strains lost their antagonistic activitiy during the two or three transfers to new growth media. The two sta-

TABLE 2. Screening of antagonistic bacteria from environmental samples.

\begin{tabular}{lcc}
\hline \multirow{2}{*}{ Sample } & \multicolumn{2}{c}{$\begin{array}{c}\text { \% (no.) of antagonistic } \\
\text { bacteria against }\end{array}$} \\
\cline { 2 - 3 } & E. coli K-12 & P. putida BH \\
\hline Fresh water (219) & $2.3(5)$ & $3.2(7)$ \\
Sea water (183) & $2.7(5)$ & $1.6(3)$ \\
Activated sludge (208) & $2.4(5)$ & $1.0(2)$ \\
Soil (213) & $1.4(3)$ & $1.4(3)$ \\
\hline Total (1054) & $1.7(18)$ & $1.4(15)$ \\
\hline
\end{tabular}

ble antagonistic bacterial strains isolated from the sea water showed the following morphological and physiological characteristics: they were grampositive, rod-shaped (0.5-0.8 × 1.5-2.0 $\mu \mathrm{m})$, nonspore forming, no-motile, and F-positive in the O-F test, showed negative oxidase activity and positive catarase activity, and formed yellow colonies.

\section{DISCUSSION}

This study was conducted to make clear and generalize what factors most strongly influence the survival of exogenous bacteria in microbial ecosystems. Survival studies were carried out using a combination of two exogenous bacterial strains and microcosms derived from four environmental samples. E. coli and $P$. putida, which were used as exogenous bacteria, are the bacterial hosts most usually used in genetic engineering. Fresh water, sea water, activated sludge, and soil samples used for preparing microcosms are the most likely ecosystems to be bioaugmented with exogenous bacteria for the purpose of bioremediation or biocontrol. Large numbers of exogenous bacteria were inoculated into microcosms to simulate intentional release or introduction.

To evaluate the stability of the $\mathrm{pBH} 500$ in the host strains, water or soil samples in the microcosms were occasionally plated onto not only the selective media but also the media without $\mathrm{Sm}$ (incubated at $28^{\circ} \mathrm{C}$ for $2 \mathrm{~d}$ ), and the segregants (host cells without plasmid $\mathrm{pBH} 500$ ) were estimated. As a result, the segregants were not detected throughout the experimental periods (data not shown). The phenotypes and morphologies of several colonies formed on the selective medium were investigated, and all the colonies tested showed the same phenotypes and morphologies as those of the inoculated GEMs. Therefore, the selective medium used in this study seemed to be specific to enumerate only the GEM. It is well documented that some bacteria can become non-culturable quickly after release into the environment. However, it was also demonstrated by comparing the viable count with the acridine orange direct count, direct viable count, most-provable-number estimates, and PCR analyses that the decline of plate counts of $E$. coli K12 introduced into either sterile or non-sterile water and soil was not due to the cell entering a viable but non-culturable state, but was simply due to their death (Bogosian et al. 1996). Therefore, viable counts of the exogenous bacteria in the microcosms represented their survival counts to a certain degree.

To individually evaluate the effects of predation by protozoa, interactions with indigenous bacteria, and starvation, intact, protozoa-free, and sterilized 
microcosms were prepared from each environmental sample, and the survival courses of the exogenous bacteria in this series of microcosms and in a sterile buffer were examined. The survival pattern in the sterile buffers should represent a basic decay property of the tested bacteria as affected by starvation in the absence of specific abiotic selective factors, while the pattern in the intact microcosms as that affected by all the abiotic and biotic factors which existed in the natural environmental samples. Filtration with 1.0$\mu \mathrm{m}$-pore-size filters or addition of cycloheximide, which was performed in preparing the protozoa-free microcosms, was thought to considerably reduce the effect of protozoan grazing, though such a treatment seems to be unable to completely remove or kill protozoa in the microcosms. Filtration with $0.22-\mu \mathrm{m}$ pore-size filters, which was performed in preparing the sterilized microcosms, should have eliminated almost all of the biotic factors except ultramicro-bacteria and bacteriophages, and autoclaving performed in preparing the sterilized microcosms should have eliminated all the biotic factors. Thus, the differences between the survival patterns in the intact microcosm and in the protozoa-free microcosm, between those in the protozoa-free microcosm and in the sterilized microcosm, and between those in the sterilized microcosm and in the sterile buffer should reflect to a certain degree the effects of the protozoa, indigenous bacteria, and starvation along with abiotic factors, respectively. Results of the survival study are summarized in
Tables 3 and 4.

The exogenous bacteria showed a slight growth (within about one order of magnitude) or very little decay in the sterile buffers with only one exception (Fig. 6D). The growth might have depended on the small amount of carbon source which was introduced into microcosms due to incomplete washing of the inoculum, and little effect of starvation on the survival capacity of exogenous bacteria was observed in this experimental system. On the other hand, the inoculated exogenous bacteria showed drastic drops in all the intact microcosms over the 7-day experimental period (more than 3 orders of magnitude in most cases). This suggested the common presence of one or more great lethal factors affecting exogenous bacteria in environments such as fresh water, sea water, activated sludge, and soil. Especially, such lethal effect was very noticeable against $P$. putida $\mathrm{BH}$ in the intact sea water microcosm in this study; this strain disappeared to below the detectable limit within $5 \mathrm{~d}$.

Compared with the survival patterns in the intact microcosms, the survival levels of exogenous bacteria were drastically enhanced (by more than 3 orders of magnitude in most cases) by the removal of almost all biotic factors (sterilized microcosms), while the partial removal or inhibition of protozoan activities (protozoa-free microcosms) hardly or only slightly enhanced their survival capacity (less than 1 order of magnitude). As the survival levels of exogenous bacteria in the sterilized microcosms did not significantly

TABLE 3. Summary of results of the survival studies of $E$. coli K-12.

\begin{tabular}{lcccc}
\hline Microcosm & $\begin{array}{c}\text { Fresh water } \\
(\mathrm{CFU} / \mathrm{ml})\end{array}$ & $\begin{array}{c}\text { Sea water } \\
(\mathrm{CFU} / \mathrm{ml})\end{array}$ & $\begin{array}{c}\text { Activated sludge } \\
(\mathrm{CFU} / \mathrm{ml})\end{array}$ & $\begin{array}{c}\text { Soil } \\
(\mathrm{CFU} / \mathrm{dry}-\mathrm{g})\end{array}$ \\
\hline Intact & $2.0 \times 10^{2}$ & $3.6 \times 10^{2}$ & $4.0 \times 10^{4}$ & $7.2 \times 10^{4}$ \\
Protozoa-free & $1.0 \times 10^{3}$ & $7.2 \times 10^{1}$ & $1.8 \times 10^{5}$ & - \\
Sterilized & $1.1 \times 10^{4}$ & $1.1 \times 10^{6}$ & $9.5 \times 10^{7}$ & $4.8 \times 10^{6}$ \\
Sterile buffer & $7.3 \times 10^{4}$ & $3.5 \times 10^{6}$ & $2.4 \times 10^{7}$ & - \\
\hline Inoculum density & $4.5 \times 10^{4}$ & $3.3 \times 10^{5}$ & $2.9 \times 10^{7}$ & $9.3 \times 10^{7}$ \\
\hline
\end{tabular}

The ultimate survival levels (on day 7 ) are summarized in comparison with the inoculated levels.

TABLE 4. Summary of results of the survival studies of $P$. putida $\mathrm{BH}$.

\begin{tabular}{lcccc}
\hline Microcosm & $\begin{array}{c}\text { Fresh water } \\
\text { (CFU/ml) }\end{array}$ & $\begin{array}{c}\text { Sea water } \\
\text { (CFU/ml) }\end{array}$ & $\begin{array}{c}\text { Activated sludge } \\
\text { (CFU/ml) }\end{array}$ & $\begin{array}{c}\text { Soil } \\
\text { (CFU/dry-g) }\end{array}$ \\
\hline Intact & $5.3 \times 10^{3}$ & $<1 \times 10^{1}$ & $2.3 \times 10^{5 a}$ & $7.7 \times 10^{4}$ \\
Protozoa-free & $2.4 \times 10^{4}$ & $<1 \times 10^{1}$ & $6.8 \times 10^{5}$ & - \\
Sterilized & $2.8 \times 10^{5}$ & $4.7 \times 10^{5}$ & $3.2 \times 10^{6}$ & $1.8 \times 10^{6}$ \\
Sterile basal salt medium & $1.5 \times 10^{5}$ & $4.1 \times 10^{5}$ & $1.3 \times 10^{6}$ & - \\
\hline Inoculum density & $2.2 \times 10^{4}$ & $3.0 \times 10^{5}$ & $5.0 \times 10^{8}$ & $1.6 \times 10^{8}$ \\
\hline
\end{tabular}

The ultimate survival levels (on day 7 ) are summarized in comparison with the inoculated levels. ${ }^{a}$ The survival level on day 5 is shown, because the intact microcosm was lost on day 6 (Fig. $6 \mathrm{~A}$ ). 
differ from those in the sterile buffers in most cases, the absence of specific abiotic factors affecting the survival of the exogenous bacteria was suggested in this study. From these data, it was indicated that the interaction with indigenous bacteria was the most influential factor causing the decline of the exogenous bacterial populations, and it seemed that this disadvantageous interaction between indigenous and exogenous bacteria leading to lethal effects took the form of the antagonism or amensalism rather than competition for nutrients and/or space. Of course, further studies on the survival of many kinds of microorganisms in various types of fresh water, sea water, activated sludge, and soil are needed.

Some researchers reported that protozoan predation seemed to be the most important factor affecting the survival of bacteria inoculated into fresh water (Amy et al., 1989; Gurijara and Alexander, 1990; Iwasaki et al., 1993), sewage (Sinclair and Alexander, 1984), and soil (Tang and Alexander, 1987), and its effect on the survival of exogenous bacteria was certainly observed in this study. However, it seemed that protozoan predation was much less influential than the existence of indigenous bacteria. Although the effect of protozoan predation in activated sludge might be underestimated owing to the decrease in their population as shown in Figs. 5 and 6 , the survival tests here seem to be able to reflect the predatory effects to a certain degree because vigorous grazing activities of surviving protozoa were often observed during the test period. It was also reported that protozoan predation was not an important lethal factor working against exogenous bacteria in model activated sludge processes (McClure et al., 1989) and soil (Zaidi et al., 1989).

On the other hand, there have been several reports on the presence of antagonistic relationships among indigenous microorganisms; however, no report has clearly asserted that this antagonism is the most important factor affecting the survival of exogenous bacteria in various microbial ecosystems. To provide evidence for the presence of antagonism between indigenous and exogenous bacteria, bacterial strains having antagonistic activities against $E$. coli $\mathrm{K}-12$ or $P$. putida $\mathrm{BH}$ were screened from environmental samples used for the survival studies. Various types of bacterial antagonistic activities have been reported, and there are some detection methods for such antagonistic bacteria. Some antagonistic bacteria produce inhibitory substances against the growth of other microorganisms ( Lemos et al., 1985; Nair and Simidu, 1987; Rosenfeld and ZoBell, 1947), and some degrade cell walls of other microorganisms with lysozyme (Tang and Alexander, 1987). To date, sea water has been known to contain substances with antagonistic activity against exogenous bacteria, and it has been suggested that such substances are produced by marine algae or bacteria (Lemos et al., 1985; Rosenfeld and ZoBell, 1947). It was reported that about $5 \%$ of bacteria isolated from sea water exhibited inhibitory activity against the growth of either Vibrio parahaemolyticus or Staphylococcus aureus (Nair and Simidu, 1987), and about $17 \%$ of bacteria isolated from intertidal seaweeds exhibited antagonistic activity against Staphylococcus aureus (Lemos et al., 1985). Some antagonistic substances produced by marine bacteria were low molecular weight compounds, thermolabile, anionic, and not affected by proteolytic enzymes (Lemos et al., 1985). In this study, the antagonistic bacteria were detected not only in sea water samples but also in fresh water and activated sludge samples at ratios of $1.0-3.5 \%$ of the indigenous heterotrophic bacteria examined. Therefore, it was confirmed that antagonistic bacteria are widely distributed in various microbial ecosystems at certain levels. However, it cannot be concluded that the number of antagonistic bacteria alone reflects the effect of their antagonistic activity on the survival of exogenous bacteria, because the antagonistic effect should depend not only on the population of antagonistic bacteria but also on their specific antagonistic activity. These results may not be completely conclusive but clearly point to the importance of the antagonistic effect of indigenous bacteria on the survival of exogenous bacteria.

Amongst the total of 33 bacterial strains with antagonistic activity against either $E$. coli $\mathrm{K}-12$ or $P$. putida $\mathrm{BH}$, only one isolated from the sea water was effective against both types of exogenous bacteria. This suggested that an antibacterial factor produced by an antagonistic bacterial strain has lethal effects on a limited number of bacterial species or strains. Interestingly, most of the antagonistic bacteria except for two strains lost their antagonistic activities while being maintained on the media, indicating that they need some specific conditions to exhibit antagonistic activities, such as trace substances present in their native microbial ecosystems. There seem to exist complex antagonistic relationships among indigenous bacterial flora, and they may play important roles in the maintenance of the diversity of the microbial ecosystems (Freitas and Fredrickson, 1978). It could be that indigenous bacteria work their antagonistic activities against exogenous bacteria so that their ecosystems will not be altered or disrupted by the populous intrusion of exogenous bacteria.

From the investigations performed here, it may be concluded that the antagonistic activities of 
indigenous bacteria is the most common and significant factor which influences the ability of exogenous bacteria to survive in natural microbial ecosystems. Further investigations, including identification of triggers to cause the antagonistic activities of indigenous bacteria and characterization of the antagonistic substances, will provide an effective control strategy for successful introduction of exogenous bacteria.

\section{REFERENCES}

Amy, P. S., Hermid, D, and Hiatt, H. D. (1989) Survival and detection of bacteria in aquatic environment. Appl. Environ. Microbiol., 55, 788-793.

Barcina, I., Arana, I., Astorga, A. F., Iriberri, J., and Egea, L. (1992) Survival strategies of plasmidcarrier and plasmidless Escherichia coli strains under illuminated and non-illuminated conditions, in a fresh water ecosystem. J. Appl. Bacteriol., 73, 229236.

Bolton, H., Fredrickson, J. K., Bentjen, S. A., Workman, D. J., Li, S. W., and Thomas, J. M. (1991) Field calibration of soil-core microcosms: Fate of a genetically altered rhizobacterium. Microb. Ecol., 21,163-173.

Bogosian, G., Sammons, L. E., Morris, P. J. L., O'neil, J. P., Heitkamp, M. A., and Weber, D. B. (1996) Death of Escherichia coli K-12 strain W3110 in soil and water. Appl. Environ. Microbiol., 62, 4114-4120.

Brettar, I., Gonzalez, M. I. R., Ramos, J. L., and Hofle, M. G. (1994) Fate of Pseudomonas putida after release into lake water mesocosm : Different survival mechanisms in response to environmental conditions. Microb. Ecol., 27, 99-122.

Freitas, M. J., and Fredrickson, A. G. (1978) Inhibition as a factor in the maintenance of the diversity of microbial ecosystems. J. Gen. Microbiol., 106, 307320.

Fujita, M., Ike, M., and Hashimoto, S. (1991) Feasibility of wastewater treatment using genetically engineered microorganisms. Water Res., 25, 979-984.

Fujita, M., Ike, M., and Uesugi, K.(1994) Operation parameters affecting the survival of genetically engineered microorganisms in activated sludge processes. Water Res., 28, 1667-1672 .

Gurijara, K. R., and Alexander, M. (1990) Explanation for the decline of bacteria introduced into lake water. Microb. Ecol., 20, 231-244.

Iwasaki, K., Uchiyama,. H., and Yagi, O. (1993) Survival and impact of genetically engineered Pseudomonas putida harboring mercury resistance gene in aquatic microcosms. Biosci. Biotechnol. Biochem., 57, 1264-1269.
Klein, T. M., and Alexander, M. (1986) Bacterial inhibitors in lake water. Appl. Environ. Microbiol., 52, 114-118.

Lemos, M. L., Toranzo, A. E., and Barja, J. L. (1985) Antibiotic activity of epiphytic bacteria isolated from intertidal seaweeds. Microb. Ecol., 11, 149-163.

Leser, T. D., Boye, M., and Hendriksen, N. B. (1995) Survival and activity of Pseudomonas sp. strain B13 (FR1) in a marine microcosm determined by quantitative PCR and an rRNA-targeting probe and its effect on the indigenous bacterioplankton. Appl. Environ. Microbiol. 61, 1201-1207.

Lindow, S. E., Panopoulos, N. J., and McFarland, B. L. (1989) Genetic engineering of bacteria from managed and natural habitats. Science, 244, 13001306.

Macnaughton, S. J., Rose, D. A., and O'Donnell, A. G. (1992) Persistence of a $x y / E$ marker gene in Pseudomonas putida introduced into soils of differing texture. J. Gen. Microbiol., 138, 667-673.

McClure, N. C., Weightman, A. J., and Fry, J. C. (1989) Survival of Pseudomonas putida UWC1 containing cloned catabolic genes in a model activated-sludge unit. Appl. Environ. Microbiol., 55, 2627-2634.

Mezrioui, N., Blaeux, B., and Troussellier, M. (1995) A microcosm study of the survival of Escherichia coli and Salmonella typhimurium in brackish water. Water Res., 29, 159-465.

Nair, S., and Simidu, U. (1987) Distribution and significance of heterotrophic marine bacteria with antibacterial activity. Appl. Environ. Microbiol., 53, 2957-2962.

Nüblein, K., Maris, D., Timmis, K., and Dwyer, D. F. (1992) Expression and transfer of engineered catabolic pathways harbored by Pseudomonas spp. introduced into activated sludge microcosms. Appl. Environ. Microbiol., 58, 3380-3386 .

Pike, E. B., Carrington, E. G., and Ashburner, P. A. (1972) An evaluation of procedures for enumerating bacteria in activated sludge. J. Appl. Bacteriol., 35, 309-321.

Ramos, J. L., Duque, E., and Gonzalez, M. I. R. (1991) Survival in soils of an herbicide-resistant Pseudomonas putida strain bearing a recombinant TOL plasmid. Appl. Environ. Microbiol., 57, 260266.

Ramos, J. L., Diaz, E., Dowling, D., Lorenzo, V., Molin, S., Ramos, F.O., and Timmis, K. N. (1994) The behavior of bacteria designed for biodegradation. Biotechnology, 12, 1349-1356.

Recorbet, G., Picard, C., Nomand, P., and Simonent, P. (1993) Kinetics of the persistence of chromosomal DNA from genetically engineered Escherichia 
coli introduced into soil. Appl. Environ. Microbiol., 59, 4289-4294.

Rosenfeld, W. D., and ZoBell, C. E. (1947) Antibiotic production by marine microorganisms. J. Bacteriol., 54, 393-398.

Sambrook, J., Fritsch, E. F., and Maniatis, T. (1989) Molecular Cloning, A Laboratory Manual, 2nd edn. Cold Spring Harbor Laboratory Press, New York.

Sinclair, J. L., and Alexander, M. (1984) Role of resistance to starvation in bacterial survival in sewage and lake water. Appl. Environ. Microbiol., 48, 410415.
Sinclair, J. L., and Alexander, M. (1989) Effect of protozoan predation on relative abundance of fast- and slow-growing bacteria. Can. J. Microbiol., 35, 578582.

Tang, Y. J., and Alexander, M. (1987) Absence of a role for lytic microorganisms in decline of bacteria and Saccharomyces introduced into soil. Microb. Ecol., 14, 67-73.

Zaidi, B. R., Murakami, Y., and Alexander, M. (1989) Predation and inhibitors in lake water affect the success of inoculation to enhance biodegradation of organic chemicals. Environ. Sci. Technol., 23, 859863. 